Gadjah Mada International Journal of Business

May-August 2009, Vol. 11, No. 2, pp. 229-252

\title{
INTEGRATION OF STOCK MARKETS BETWEEN INDONESIA AND ITS MAJOR TRADING PARTNERS
}

\author{
Bakri Abdul Karim \\ Faculty of Economics and Business, \\ Universiti Malaysia Sarawak, Malaysia \\ M. Shabri Abd. Majid \\ Kulliyah of Economics and Management Sciences, \\ Interantional Islamic University of Malaysia (IIUM), Malaysia \\ Samsul Ariffin Abdul Karim \\ Universiti Teknologi Petronas, Malaysia
}

Using Autoregressive Distributed Lag (ARDL) and Vector Autoregressive (VAR) frameworks, this study examines the integration between the emerging stock market of Indonesia and its major trading partners (i.e., Japan, the U.S., Singapore, and China). During the period of July 1998 to December 2007, the Indonesian stock market is found to be integrated with its major trading partners. Thus, this implies that there is a limited room available for investors to gain risk-reduction benefits through diversifying their portfolio in those markets. Meanwhile, in the short run, the Indonesian market responds more to shocks in the U.S. and Singapore than in Japan and China. In designing policies pertaining to its stock market, the Indonesian government should take into account any development in the stock markets of its major trading partners, particularly the U.S. and Singaporean markets.

Keywords: ARDL; Indonesia; international portfolio diversification; stock market integration; trading partners 
Gadjah Mada International Journal of Business, May-August 2009, Vol. 11, No. 2

\section{Introduction}

The subject of dynamic interdependence amongst stock markets has become an important topic of growing interest recently. The interest in stock market integration arises primarily because financial theory suggests that an integrated regional stock market is more efficient than segmented national capital markets. With an integrated regional stock market, investors from all member countries will be able to allocate capital to the locations in the region where it is the most productive (Click and Plummer 2005). In addition, the degree of stock market integration has major implications on potential benefits of international portfolio diversification and on financial stability of a country (Ibrahim 2005). Stock market integration tends to create a long-run equilibrium relationship, which ties price movements in national stock indices and could considerably reduce benefits from international portfolio diversification. Thus, information on international stock market linkages is relevant not only to portfolio managers, but also to international economic and financial policymakers.

The widening of economic interdependence in Asia has been paralleled by a deepening of interdependence through rising intra-regional trade and investment. Until the mid1980s, trade in Asia was dominated by exports across the Pacific. With Asia growing much faster than the U.S., and trade friction between the two sides of the Pacific escalating, intra-regional trade amongst Asian countries has increased sharply while the relative importance of the U.S. as an export market for these countries has declined (Kwan 2001). Intra-regional trade expansion is one of the efficient ways of integrating to the much larger international economy as the countries become more competitive (Chowdhury 2005). In addition, Kearney and Lucey (2004) note that the world's economic and financial systems are becoming increasingly integrated due to the rapid expansion of international trade in commodities, services, and financial assets.

As globalisation and regionalism gained its momentum from the beginning of 1980s and the gain from open trade was realised by the pioneer East Asian, especially the Association of Southeast Asian Nations (ASEAN), other Asian countries also tried to move toward intra-regional economic cooperation. Cooperation amongst the neighbours not only strengthens the economic and financial integration, but also enhances greater political stability and social cooperation between member nations (Chowdhury 2005). Thus, trade linkages across ASEAN members have been seen as one of contributors to enhancing financial integration in the region.

There have been many studies investigating financial integration from different perspectives such as stock markets, bond markets, and exchange rates, including regional trade arrangements and Yen bloc. Earlier studies on 
the stock market integration (e.g., Grubel 1968; Levy and Sarnat 1970; Solnik 1974) find lower correlations amongst national stock markets, thereby suggesting potential benefits of international portfolio diversification. Goldstein and Michael (1993) document increasing international stock market linkages over the past decade, especially for the stocks traded actively in the major financial centres. The impacts of the October 1987 stock market crash and the 1997 Asian financial crisis on stock market integration have also drawn much attention amongst economists and practitioners (for instance, Arshanapalli et al. 1995; Francis et al. 2002; and Yang et al. 2003). They note that the stock markets have become more cointegrated after the crisis.

The vast growing economic activities and the increasing investment opportunities in some Asian emerging markets in recent years have attracted investors' and researchers' attention. Examples of these recent studies include Cheung and Mak (1992), Hung and Cheung (1995), Palac-McMiken (1997), Roca et al. (1998), Janakiramanan and Lamba (1998), Masih and Masih (1999), Azman-Saini et al. (2002), Ng (2002), Ibrahim (2005), and Majid et al. (2008). It is well documented that the U.S. market is the most dominant in influencing variations in other developed and emerging equity markets. The U.S. market is a 'global factor' which leads most of the Asian emerging markets (Cheung and Mak 1992). Consistent with Arshanapalli et al.(1995), Ibrahim (2005) provides evidence that the ASEAN markets respond quickly to shocks in the U.S. regardless of the sample period but seem to be less influenced by the Japanese market. However, Yang et al. (2003) find that more Asian markets, including Indonesia, significantly respond to innovations in the Japanese market.

Using monthly data from January 1987 to October 1995 and cointegration approach, Palac-McMiken (1997) finds that, with the exception of Indonesia, all other ASEAN markets are linked to each other. In contrast, Roca et al. (1998) find no evidence of cointegration amongst them. However, with the exception of Indonesia, these markets have significant short-run linkages. Janakiramanan and Lamba (1998) also find that the Indonesian market is a relatively isolated market. Using Granger non-causality test and weekly data from January 1988 to August 1999, Azman-Saini etal.(2002) find the dominance of the Singaporean market in the region. With the exception of Malaysia, the Indonesian market is affected by other ASEAN markets but does not significantly influence the other markets. On the other hand, Click and Plummer (2005) document that the ASEAN-5 markets including Indonesia are integrated in the economics sense, but that integration is far from complete.

Ibrahim (2005) examined the international linkage of the Indonesian stock market during the pre- and postcrisis periods using cointegration and 
Gadjah Mada International Journal of Business, May-August 2009, Vol. 11, No. 2

vector autoregression(VAR). He finds evidence for the lack of cointegration between the Indonesian markets with other ASEAN members and with the most advanced markets (the U.S. and Japan) during both periods. In addition, the Indonesian markets become more segmented from other ASEAN markets but more responsive to the developed markets (the U.S. and Japan)during the post-crisis period. Thus, past studies have documented a particularly interesting finding that the Indonesian market seems to be generally segmented from the advanced markets and other ASEAN markets, both in short and long runs. However, these markets are going toward a greater integration, either amongst themselves or with the U.S. and Japan, especially in the post-1997 financial crisis (Ng 2002; Majid et al. 2008).

McCauley et al. (2002) examined the East Asia's bond and loan markets integration for the period of 19992002. They find that both markets become more integrated. In contrast, in their recent study, Yu et al. (2007) find weak bond market integration in the region during 1997 to 2003 period. They note that the lack of progress might be due to the "local" or "idiosyncratic" factors in some Asian economies. Plummer and Click (2005) argue that the deepening of local bond markets could strengthen the financial integration. As for the exchange rate integration, Aggarwal and Mougoue (1996) document that Asian currencies are cointegrated with the influence of the Japanese Yen increasing relative to the U.S. dollar in recent years. Since 1980, economic integration amongst Japan's neighbours has been intensified and their business cycles have been highly synchronised. These cycles have been closely linked to fluctuations in the Yen/Dollar exchange rate - through changes in the export competitiveness, inflows of foreign direct investment, and intraAsian income effects (McKinnon and Schnabl 2003).

The interest in a Yen bloc in Asia has been on the rise because of a deepening economic interdependence between Japan and its neighbours. The onset of the Asian currency crisis, the introduction of the Euro in Europe, and the implementation of Japan's financial reform program have contributed to ongoing discussions on the possibility amongst policymakers in those countries (Kwan 2001). With Yen bloc, Japan would become the centre of gravity of the Asian Pacific economy. As the region becomes increasingly integrated, more business activity goes into the gravitational pull of Japan and its corporations. Trade and investment within the region would continue to grow faster than the rest of the world.

Although there have been numerous studies investigating financial integration amongst emerging markets, but none of them has focused its analysis on whether the Indonesian stock market is integrated with its major trading partners such as Japan, the United States (henceforth the U.S.), Singapore, and People's Republic of 
Karim et al.-Integration of Stock Markets between Indonesia and Major Trading Partners

China (henceforth China). In addition, Roll (1995) affirms that although Indonesia has had an active equity market for a number of years, very few empirical studies on this market have appeared in Western scholarly journals. Some other studies included Indonesia in their sample as part of broader studies of stock market inte- gration in Asia Pacific markets (e.g., Janakiraman and Lamba 1998; Masih and Masih 1999; Ng 2002; Daly 2003; Yang et al. 2003; Majid et al. 2008). Thus, this study tries to fill the gap on existing research by examining the integration between the Indonesian market and its major trading partners.

Table 1. International Trade between Indonesia and Its Major Trading Partners, 2000-2007

\begin{tabular}{|c|c|c|c|c|c|}
\hline Year & JPN & US & SING & CHN & Subtotal \\
\hline \multicolumn{6}{|c|}{ Panel A: \% Share of exports to countries out of total exports } \\
\hline 2000 & 23.21 & 13.67 & 10.56 & 4.46 & 51.89 \\
\hline 2001 & 23.10 & 13.78 & 9.52 & 3.91 & 50.31 \\
\hline 2002 & 21.07 & 13.24 & 9.36 & 5.08 & 48.76 \\
\hline 2003 & 22.30 & 12.11 & 8.85 & 6.23 & 49.49 \\
\hline 2004 & 22.31 & 12.28 & 8.39 & 6.44 & 49.41 \\
\hline 2005 & 21.08 & 11.55 & 9.15 & 7.78 & 49.56 \\
\hline 2006 & 19.39 & 11.48 & 11.82 & 7.70 & 50.39 \\
\hline 2007 & 18.56 & 10.93 & 10.54 & 8.76 & 48.79 \\
\hline Average & 21.38 & 12.38 & 9.77 & 6.29 & 49.83 \\
\hline Average export growth & 7.83 & 7.99 & 13.52 & 23.73 & 10.63 \\
\hline Average growth total & 11.40 & & & & \\
\hline \multicolumn{6}{|c|}{ Panel B: \% Share of imports from countries out of total imports } \\
\hline 2000 & 16.10 & 10.12 & 11.31 & 6.03 & 43.57 \\
\hline 2001 & 15.14 & 10.37 & 10.16 & 5.95 & 41.63 \\
\hline 2002 & 14.09 & 8.45 & 13.10 & 7.76 & 43.40 \\
\hline 2003 & 12.99 & 8.30 & 12.77 & 9.08 & 43.14 \\
\hline 2004 & 13.07 & 6.96 & 13.07 & 8.81 & 41.92 \\
\hline 2005 & 11.97 & 6.73 & 16.41 & 10.13 & 45.24 \\
\hline 2006 & 8.76 & 3.66 & 29.59 & 11.24 & 53.25 \\
\hline 2007 & 8.58 & 4.08 & 28.38 & 12.23 & 53.27 \\
\hline Average & 12.59 & 7.33 & 16.85 & 8.90 & 45.68 \\
\hline Average import growth & 10.34 & 6.25 & 46.33 & 34.02 & 26.00 \\
\hline Average growth total & 21.17 & & & & \\
\hline
\end{tabular}

Source: Asian Development Bank (2008). 
It is the fact that Indonesia is a growing and relatively open economy with trade and foreign direct investment play significant role in driving its economy. The opening of the equity markets in Indonesia and other Asian emerging markets during the 1980s has resulted in a rising interest in investing in these markets. This is evidenced by the creation of huge various investment funds that focus on this region by international fund management houses (Hung and Cheung 1995). We consider whether the Indonesian stock market is integrated with the stock markets of Japan, the U.S., Singapore, and China because of the importance of these economies to Indonesia as trading partners and in terms of investment flows. Taylor and Tonks (1989) and Chen and Zhang (1997) note that a stronger financial integration would be expected amongst countries that reduce trade barriers and develop stronger economic ties. The stronger the bilateral trade ties between two countries, the higher of comovements (Masih and Masih 1999; Bracker et al. 1999). Shares of exports and imports from Indonesia to these four countries are relatively high. Table 1 shows the total volume of exports and imports were about 48.79 percent (USD61.704 billion) and 53.27 percent(USD60.831 billion), respectively, in the end of 2007.

The purpose of this paper is to examine the stock market integration and short-run dynamic interactions between the Indonesian stock market and the stock markets of its major trading partners (i.e., Japan, the U.S., Singapore, and China). This paper contributes to literature in three ways. First, we examine the stock market integration amongst Indonesia and its four major trading partners which has not been documented in the previous literature. Second, this paper differs from previous studies because this study employs recent newly developed procedure of autoregressive distributed lag (ARDL) bounds testing approach (Pesaran et al. 2001) to examine the stock market integration (longrun equilibrium relationship). This methodology to the best of our knowledge goes clearly beyond the existing literature on the subject in Indonesia. Current studies have indicated that the ARDL approach or bounds testing approach to cointegration is preferable to other conventional cointegration approaches such as Engle and Granger (1987), Gregory and Hansen (1996), Johansen (1988), and Johansen and Juselius (1990). For example, Atkin and Coe (2002) note that a potential weakness of all the above techniques is that they require the underlying time series to be non-stationary. Third, this study utilizes recent postcrisis weekly data from July 1998 to December 2007. We attempt to assess the recent evidence of long-run relationships and short-run dynamic interactions between the Indonesian stock market and the stock markets of its major trading partners, and in particular to what extent the Indonesian market is influenced by those of its trading partners. 
The rest of the paper is organized as follows. Section 2 describes the empirical framework, and provides the description of the data. Section 3 offers empirical results and discussion. Finally, Section 4 presents concluding remarks.

\section{Empirical Framework and Data Preliminaries}

We use ARDL bounds testing approach and Vector Autoregressive (VAR) framework to examine the stock market integration and short-run dynamic interactions between Indonesia and its major trading partners. We use ARDL to test the stock market integration while VAR provides short-run dynamic interactions amongst these markets.

\section{ARDL Model}

The study employs the ARDL bounds testing approach to investigate the cointegration relationship amongst the Indonesian stock market and the stock markets of its major trading partners. The bounds testing procedure does not require the pre-testing of the variables included in the model for unit roots unlike other techniques such as the Johansen and Juselius' (1990) approach. It also allows for inference on long-run estimates, which are not possible under alternative cointegration procedure. Additionally, another advantage of the ARDL is the ARDL model takes sufficient number of lags to capture the data-generating process in a general-to-specific modelling framework. It estimates $(p+1)^{\mathrm{k}}$ number of regressions to obtain optimal lag-length for each variable, where $p$ is the maximum lag, and $k$ is the number of variables in the equation (Laurenceson. and Chai 2003). In addition, the bounds test procedure is simple. As opposed to other multivariate cointegration techniques such as Johansen and Juselius (1990), it allows the cointegration relationship to be estimated by ordinary least squares (OLS) once the lag order of the model is identified (Fosu and Magnus 2006).

Pesaran and Shin (1995) show that with the ARDL framework, the OLS estimators of the short-run parameters are consistent, and the ARDL based estimators of the long-run coefficients are super-consistent in small sample sizes. However, Narayan et al. (2004) note that increasing the number of observations using high frequency data does not add robustness to the cointegration results because what matters is the length of the period rather than the number of observations. The ARDL procedure involves two stages. In the first stage, we establish a long-run relationship that exists amongst the variables. The second stage involves estimating the long-run and short-run coefficients of equations conditional on whether the variables are cointegrated. Details of the mathematical derivation of the long-run and short-run parameters can be found in Pesaran et al. (2001). The error correction version of the ARDL model 
Gadjah Mada International Journal of Business, May-August 2009, Vol. 11, No. 2

relating to the five stock markets incorporated in our study is stated as follows:

$$
\begin{aligned}
\Delta \mathrm{INA}_{\mathrm{t}}= & \alpha_{0}+\sum_{\mathrm{i}=1}^{\mathrm{p}} \lambda_{1 \mathrm{i}} \Delta \mathrm{INA}_{\mathrm{t}-\mathrm{i}}+\sum_{\mathrm{i}=0}^{\mathrm{p}} \lambda_{2 \mathrm{i}} \Delta \mathrm{JPN}_{\mathrm{t}-\mathrm{i}} \\
& +\sum_{\mathrm{i}=0}^{\mathrm{p}} \lambda_{3 \mathrm{i}} \Delta \mathrm{US}_{\mathrm{t}-\mathrm{i}}+\sum_{\mathrm{i}=0}^{\mathrm{p}} \lambda_{4 \mathrm{i}} \Delta \mathrm{SING}_{\mathrm{t}-\mathrm{i}} \\
& +\sum_{\mathrm{i}=0}^{\mathrm{p}} \lambda_{5 \mathrm{i}} \Delta \mathrm{CHNN}_{\mathrm{t}-\mathrm{i}}+\delta_{1} \mathrm{INA}_{\mathrm{t}-\mathrm{i}} \\
& +\delta_{2} \mathrm{JPN}_{\mathrm{t}-\mathrm{i}}+\delta_{3} \mathrm{US}_{\mathrm{t}-\mathrm{i}}+\delta_{4} \mathrm{SING}_{\mathrm{t}-\mathrm{i}} \\
& +\delta_{4} \mathrm{CHN}_{\mathrm{t}-\mathrm{i}}+\varepsilon_{\mathrm{t}}
\end{aligned}
$$

where $\Delta$ is the difference operator; INA, JPN, US, SING and CHN refer to Indonesia, Japan, the U.S., Singapore, and China, respectively; $\varepsilon$ is white noise error term. The following are steps to test the cointegration relationship amongst the stock market of Indonesia and Japan, the U.S., Singapore, and China. Firstly, we estimate Equation (1) by OLS technique. Pesaran et al. (2001) note that the model above is based on an assumption that the error term is serially uncorrelated. Therefore, it is important that the lag order $p$ of the underlying model is chosen appropriately. The order of the distributed lag on the dependent variable and the regressors is selected using either Akaike Information Criterion (AIC) or the Schwartz Bayesian Criterion (SBC). SBC selects the smallest possible lag length while AIC selects the maximum relevant lag length. Since we use weekly data, we use appropriate lag length based on Akaike Infor- mation Criterion (AIC) (Akaike 1974) with no serial correlation in the model.

Secondly, the presence of cointegration is traced by restricting all estimated coefficients of lagged level variables equal to zero. That is, the null hypothesis $\mathrm{H}_{0}: \delta_{1}=\delta_{2}=\delta_{3}=\delta_{4}=$ $\delta_{5}=0$ against the alternative, hypothesis $H_{a}: \delta_{1} \neq \delta_{2} \neq \delta_{3} \neq \delta_{4} \neq \delta_{5} \neq 0$. These hypotheses can be examined using the critical values bounds as tabulated in Pesaran et al. (2001). The relevant critical value bounds are based on case III with unrestricted intercepts and no trend, and the number of regressors, $\mathrm{k}$, are four. If the computed $F$-statistic is less than lower bound critical value, then we do not reject the null hypothesis of no integration. However, if the computed $F$-statistics is greater than upper bound critical value, then we reject the null hypothesis and conclude that there exists steady state equilibrium between the variables under study. However, if the computed value falls within lower and upper bound critical values, then the result is inconclusive.

\section{VAR Framework}

In order to assess short-run dynamic interactions amongst the share prices, we use VAR model of variance decomposition and impulse response function. Traditionally, VAR model as suggested by Sims (1980) relies on a Choleski's factorization to orthogonalize VAR innovations so that they are uncorrelated contemporaneously. Variance decomposition measures the 
Karim et al.-Integration of Stock Markets between Indonesia and Major Trading Partners

percentage of a market's forecast error variance that occurs as a result of a shock from a market in the system. Meanwhile, an impulse response function (IRF) traces the response of one market to a change in one of the market's innovations. This IRF enables us to characterize the dynamic integration amongst markets, and observe the speed of adjustment of markets in the system. Unfortunately, innovation accounting results based on the Choleski's factorization are sensitive to the ordering of variables when the residual covariance matrix is nondiagonal (Yang et al. 2003). Thus, in order to overcome the drawback, instead of using IRF, we employ generalized impulse response analysis as developed by Pesaran and Shin(1998), which is invariant to the ordering of the variables in the VAR model. This feature of the generalized impulse responses is particularly useful for studies on equity markets, which are generally characterized by quick price transmissions and adjustments (Ewing et al. 2003). A convenient feature of the VAR representation is that it can be estimated by OLS, which yields consistent, asymptotically efficient estimates and allows us to examine whether more complex transmission mechanism are involved (Hutson et al. 2008).

However, using VAR in level may be spurious and misleading if log level variables are non-stationary. Transforming the variables into first differences to render the variables stationary before running VAR, however, introduces misspecification problem in the case that the variables under consideration are cointegrated (Ibrahim 2005). For proper specification of the VAR model so as to avoid spurious regression, cointegration test outlined in the previous step is necessary. In particular, the findings that the variables are non-stationary and are not cointegrated suggest the use of VAR model in first differences. However, if they are cointegrated, a vector error correction model or a level VAR can be used (Engle and Granger 1987). MacDonald and Kearney (1987) also suggest that if the variables appear to be cointegrated, VAR in level (with no cointegration restrictions) rather than VAR in differenced form are applied. In addition, Monte Carlo evidence seems to confirm the claimed superiority of testing based on VAR in level (Mosconi and Giannini 1992). Thus, in our case, anticipating cointegration amongst share prices, we use the VAR with variables in level for the analysis.

\section{Data Preliminaries}

The data utilized in this study are weekly stock indices spanning from July 1998 to December 2007. The study employs weekly data instead of higher frequency data to avoid the problem of non-synchronous trading. The daily data contain too much noise and are subject to the problem of non-synchronous infrequent trading (Ibrahim 2005). Thus, this might lead to erroneous conclusion in the lead-lag relationships amongst the variables. However, the problem could be reduced if 
Gadjah Mada International Journal of Business, May-August 2009, Vol. 11, No. 2

a weekly interval of the indices is used (Hung and Cheung 1995, p. 282). The following indices are used to represent the markets: Jakarta Composite Index (JCI) for Indonesia, Standard and Poor's 500 (S\&P 500) Index for the U.S., Tokyo Price Index (TOPIX) for Japan, Singapore Straight Time Index (SSTI) for Singapore, and Shenzhen Stock Exchange Composite Index (SSE-CI) for China. All indices are based on local currency and are collected from the Bloomberg Database. Ding et al. (1999) note that there is nothing in the cointegration methodology that requires the series be in the same currency. All series are transformed into natural logarithm.
Table 2 presents the descriptive statistics of the data, including sample means, maximums, minimums, standard deviations, skewness, kurtosis, as well as the Jarque-Bera statistics and p-values. The highest mean return is 0.36 percent in Indonesia while the lowest is 0.03 percent in Japan. The standard deviations range from 2.36 percent in the U.S. (the least volatile) to 3.80 percent in Indonesia (the most volatile). All weekly market returns, have excess kurtosis (greater than 3), which means that they have a thicker tail and a higher peak than a normal distribution. The Jarque-Bera statistics and p-values indicate the rejection of normality on these five markets'

Table 2. Summary Statistics of the Market Returns

\begin{tabular}{|c|c|c|c|c|c|}
\hline & INA & JPN & US & SING & CHN \\
\hline Mean & 0.0036 & 0.0003 & 0.0005 & 0.0023 & 0.0026 \\
\hline Maximum & 0.1629 & 0.0730 & 0.0749 & 0.1366 & 0.1140 \\
\hline Minimum & -0.1763 & -0.0987 & -0.1233 & -0.1205 & -0.1076 \\
\hline Std. Dev. & 0.0380 & 0.0262 & 0.0236 & 0.0295 & 0.0339 \\
\hline Skewness & -0.0468 & -0.2543 & -0.5240 & 0.0824 & 0.2306 \\
\hline Kurtosis & 6.1092 & 3.1679 & 5.8085 & 5.5787 & 4.1666 \\
\hline Jarque-Bera & $199.569^{* * *}$ & $5.916^{* *}$ & $185.336^{* * *}$ & $137.715^{* * *}$ & $32.458^{* * *}$ \\
\hline
\end{tabular}

Note: ${ }^{* * *}$ and ${ }^{* *}$ indicate significance at the 1 percent and 5 percent levels, respectively.

Table 3. Correlation of the Market Returns

\begin{tabular}{|c|c|c|c|c|c|}
\hline & INA & JPN & US & SING & CHN \\
\hline INA & 1.0000 & & & & \\
\hline JPN & 0.2832 & 1.0000 & & & \\
\hline US & 0.1858 & 0.3958 & 1.0000 & & \\
\hline SING & 0.4254 & 0.4649 & 0.4538 & 1.0000 & \\
\hline $\mathrm{CHN}$ & 0.1018 & 0.0845 & 0.0160 & 0.1152 & 1.0000 \\
\hline
\end{tabular}


weekly return data set. The findings from the preliminary analysis for the Indonesian stock market are in line with the studies of Palac-McMiken (1997), Ibrahim (2005), and Majid et al. (2008).

Table 3 provides the correlation matrix amongst weekly marketreturns. The correlations amongst various stock markets returns are positively and generally significantly different from zero. Only the relatively isolated market of China exhibits low and statistically insignificant correlations with the most other markets. We also note that the correlation of Indonesia-Singapore is higher than other Indonesia's trading partners. This might be due to geographic proximity and close relationship between the two stock markets.

\section{Empirical Results}

\section{ARDL Results}

Before estimating the short- and long-run relationships amongst the variables, we have to decide the laglength on the first difference variables. Pesaran and Shin (1998) note that ARDL model requires a priori knowledge of the orders of the extended ARDL that is sufficient to simultaneously correct for residual serial correlation and the problem of endogenous regressors. In this study, the order of the distributed lag on the dependent variable and the regressors is selected using AIC with no serial correlation in the model. Based on AIC, the optimal lag-length is found to be three.
Turning to the result of the bound tests for cointegration, the computed F-statistic for examining the existence of a long-run relationship amongst Indonesia, Japan, the U.S., Singapore, and China is 3.63. The relevant critical value bounds are obtained from Pesaran et al. (2001), where the critical values in the case of four regressors are 2.864.01 at the 5 percent significance level, and $2.45-3.52$ at the 10 percent significance level. The results indicate that the null hypothesis of no cointegration can be rejected at 10 percent significance level (the F-statistics exceed the upper bound critical values). Thus, we find evidence the existence of long-run relationship amongst Indonesia, Japan, the U.S., Singapore, and China.

Following the establishment of the existence of cointegration, in the second stage, we retain the lagged level of variables and estimate the long-run and short-run models using AIC lag selection criterion (with maximum order set at 3). The long-run coefficient estimates are reported in Table 4 while the estimates of the error correction model (ECM) (short-run coefficients) are presented in Table 5. We use ECM to confirm the existence of a stable long-run relationship and cointegration relationship amongst variables. From Table 4, the results indicate the existence of a long-run impact of Singapore on Indonesia. However, there is no long-run impact of Japan, the U.S., and China on Indonesia. According to Ibrahim (2003), the negative coefficients imply that 
Gadjah Mada International Journal of Business, May-August 2009, Vol. 11, No. 2

the markets are competing with each other while the positive coefficients imply that the markets are complementary in nature. Thus, the results suggest that the Singaporean and the Indonesian stock markets are complementary in nature rather than competing.

Table 4. Estimated Long-run Coefficients using the ARDL $(1,1,3,1,3)$ Model

\begin{tabular}{|c|c|c|}
\hline Regressor & Coefficient & t-statistics \\
\hline JPN & -1.5708 & -1.3089 \\
\hline US & -0.8548 & -0.5991 \\
\hline SING & $3.8578^{* * *}$ & 5.1676 \\
\hline $\mathrm{CHN}$ & -0.2466 & -0.9543 \\
\hline Constant & -3.7465 & -0.8113 \\
\hline
\end{tabular}

Note: ${ }^{* * *}$ indicates significance at the 1 percent level.

Table 5. Error Correction Representation of ARDL (1,1,3,1,3) Model

\begin{tabular}{|c|c|c|}
\hline Regressor & Coefficient & t-statistic \\
\hline$\triangle \mathrm{JPN}$ & 0.1347 & 1.9631 \\
\hline$\Delta \mathrm{US}$ & -0.0624 & -0.8175 \\
\hline$\Delta \mathrm{US}_{\mathrm{t}-1}$ & 0.0164 & 0.2413 \\
\hline$\Delta \mathrm{US}_{\mathrm{t}-2}$ & $0.2107^{* * *}$ & 3.2388 \\
\hline$\Delta$ SING & $0.5312^{* * *}$ & 8.2964 \\
\hline$\Delta \mathrm{CHN}$ & 0.0572 & 1.2520 \\
\hline$\Delta \mathrm{CHN}_{\mathrm{t}-1}$ & $-0.0765^{*}$ & -1.6758 \\
\hline$\Delta \mathrm{CHN}_{\mathrm{t}-2}$ & $-0.0782^{*}$ & -1.7092 \\
\hline Constant & -0.0693 & -0.8345 \\
\hline $\mathrm{ECM}_{\mathrm{t}-1}$ & $-0.0185^{* * *}$ & -2.7319 \\
\hline \multicolumn{3}{|c|}{ Diagnostic Tests } \\
\hline $\mathrm{R}^{2}$ & \multicolumn{2}{|c|}{0.2505} \\
\hline Adj-R ${ }^{2}$ & \multicolumn{2}{|c|}{0.2302} \\
\hline F-statistic & \multicolumn{2}{|c|}{$17.7902^{* * *}$} \\
\hline DW-statistic & \multicolumn{2}{|c|}{2.1218} \\
\hline
\end{tabular}

Note: ${ }^{* * *}$ and ${ }^{*}$ indicate significance at the 1 percent and 10 percent levels, respectively. 
Table 5 shows that the coefficient of the ECM is negative and highly significant at 1 percent level. This confirms the existence of a stable long-run relationship and indicates to a longrun cointegration relationship amongst variables. The ECM corresponds to the speed of adjustment to restore equilibrium in the dynamic model following disturbances. The coefficient of the ECM is -0.0185 , implying that a deviation from the long-run equilibrium following short-run disturbances is corrected by about 1.85 percent after one week.

The performance of our estimated error correction representation for ARDL seems to be acceptable. Although the Adjusted $R^{2}$ value is relatively low, it is still acceptable since the estimate is based on the first-difference values. The diagnostic tests perform well, supporting the overall validity of the short-run model.

\section{VAR Results}

Given the existence of cointegration, a vector error correction model or a level VAR can be used (Engle and Granger 1987). Since cointegration amongst share prices are found, we use the VAR with variables in level for the analysis. As aforementioned, using Choleski's decomposition, the results of variance decomposition and impulse response function may be sensitive to the ordering of the variables. Thus, in addition to variance decomposition, we also employ generalized impulse response analysis as devel- oped by Pesaran and Shin (1998), which is invariant to the ordering of the variables in the VAR model. Firstly, we present the results of variance decomposition. Secondly, we provide the generalized impulse response function in order to assess short-run dynamic interaction amongst the Indonesian stock market and the stock market of its major trading partners.

The orderings that we choose to generate variance decompositions are: the U.S., Japan, Singapore, China, and Indonesia. Table 6 shows the VDCs (up to 10 weeks) for Indonesia. Several conclusions can be obtained from the VDC results as shown in Table 6. Firstly, we find that the Indonesia's forecast error variance is accounted for mostly by its own innovations. Secondly, with the exception of China, the innovations in other stock markets lead to fluctuations on the Indonesian stock market. Thirdly, we notice that the variations on the Indonesian stock market respond more to shocks in both the U.S. and Singaporean markets. However, for the first three weeks, the Indonesian stock marketresponds more to shocks in Singapore than to other trading partners. This might be due to geographic proximity and close relationship between the two stock markets. Our finding is in line with those of Janakiramanan and Lamba (1998) and Ng (2002), which document that geographically and economically close countries should exhibit a higher level of market integration. 
Gadjah Mada International Journal of Business, May-August 2009, Vol. 11, No. 2

Table 6. Variance Decomposition of INA

\begin{tabular}{|c|c|c|c|c|c|}
\hline Period & INA & JPN & US & SING & CHN \\
\hline 1 & 79.737 & 4.429 & 4.397 & 11.188 & 0.2459 \\
\hline 2 & 74.280 & 4.717 & 7.469 & 13.401 & 0.130 \\
\hline 3 & 69.578 & 4.095 & 12.320 & 13.816 & 0.188 \\
\hline 4 & 61.765 & 3.460 & 17.352 & 17.216 & 0.204 \\
\hline 8 & 52.489 & 1.963 & 23.891 & 21.470 & 0.185 \\
\hline 10 & 50.650 & 1.614 & 24.956 & 22.582 & 0.196 \\
\hline
\end{tabular}

Figure 1. Responses of Indonesia to Shocks in Its Major Trading Partners

Response to Generalized One S.D. Innovations \pm 2 S.E.
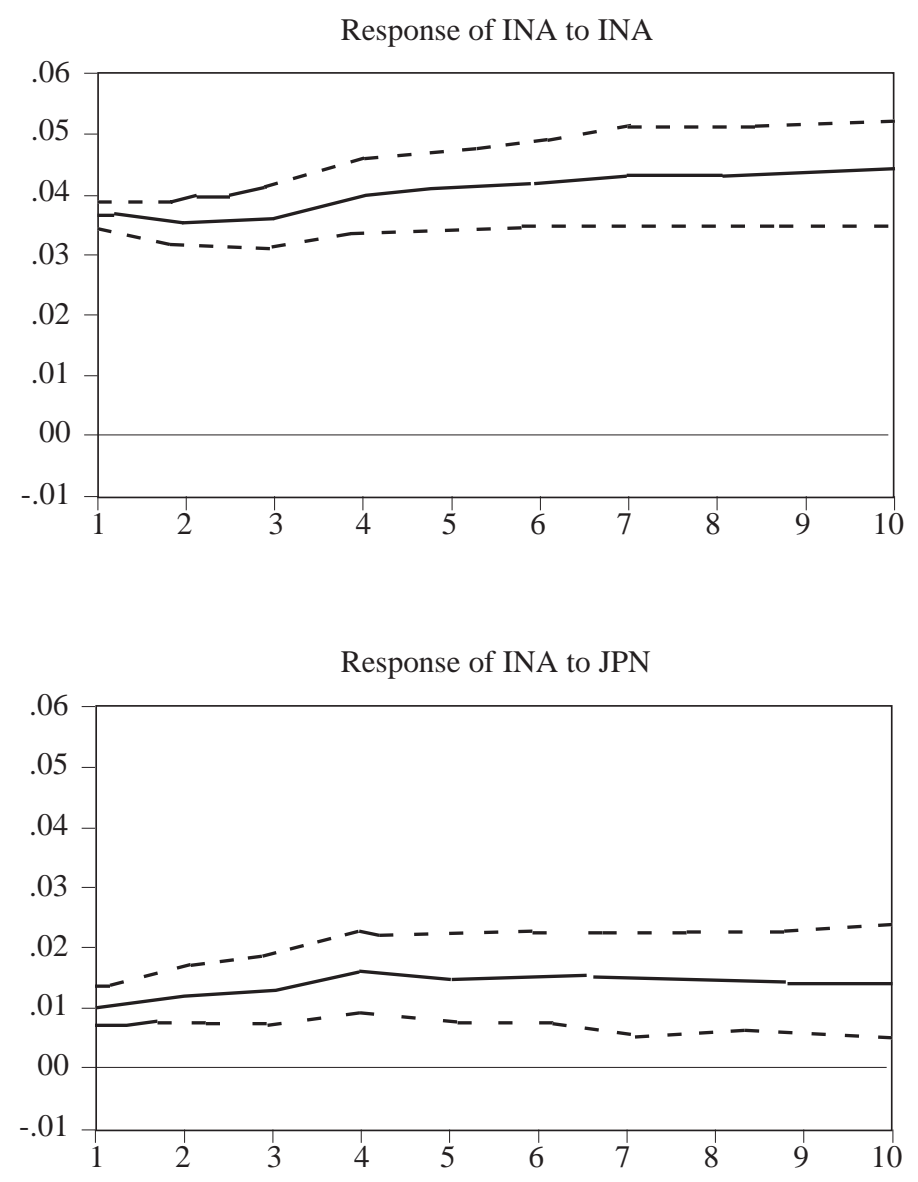
Karim et al.-Integration of Stock Markets between Indonesia and Major Trading Partners

\section{Continued from Figure 1}

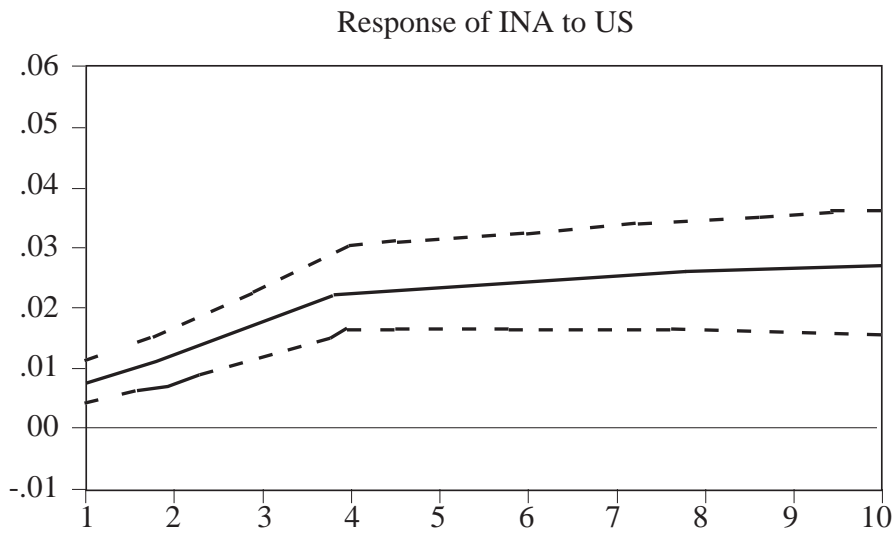

Response of INA to SING
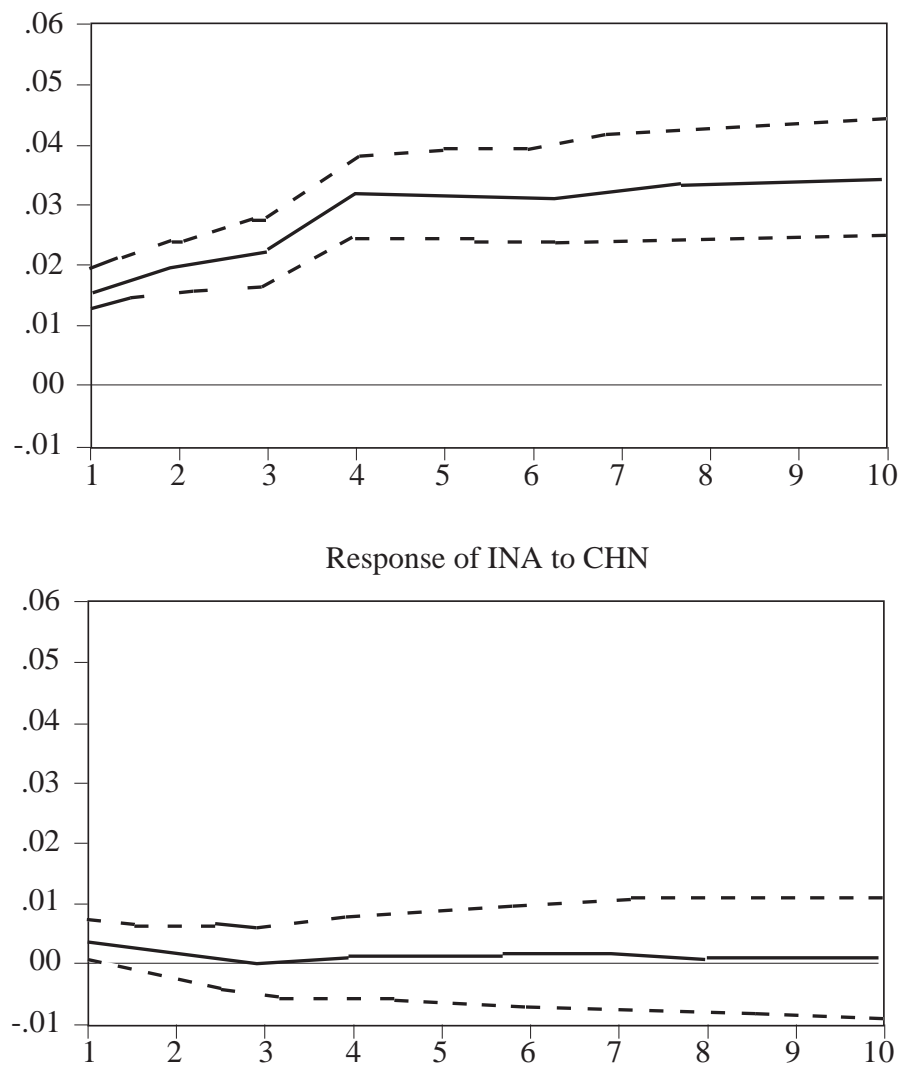
Gadjah Mada International Journal of Business, May-August 2009, Vol. 11, No. 2

Figure 2. Responses of Major Trading Partners to Shock in Indonesia

Response to Generalized One S.D. Innovations \pm 2 S.E.

Response of JPN to INA

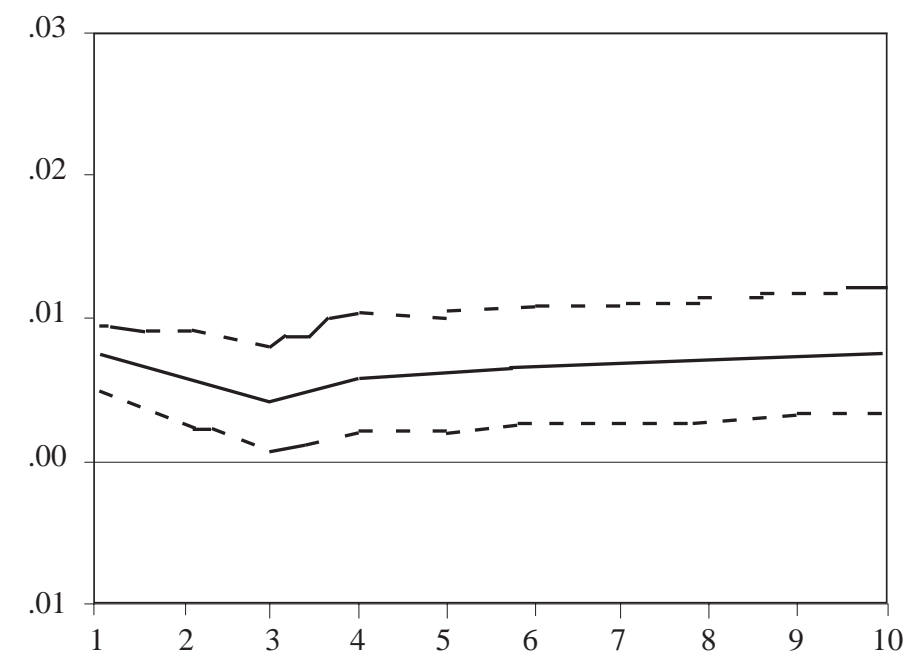

Response of US to INA

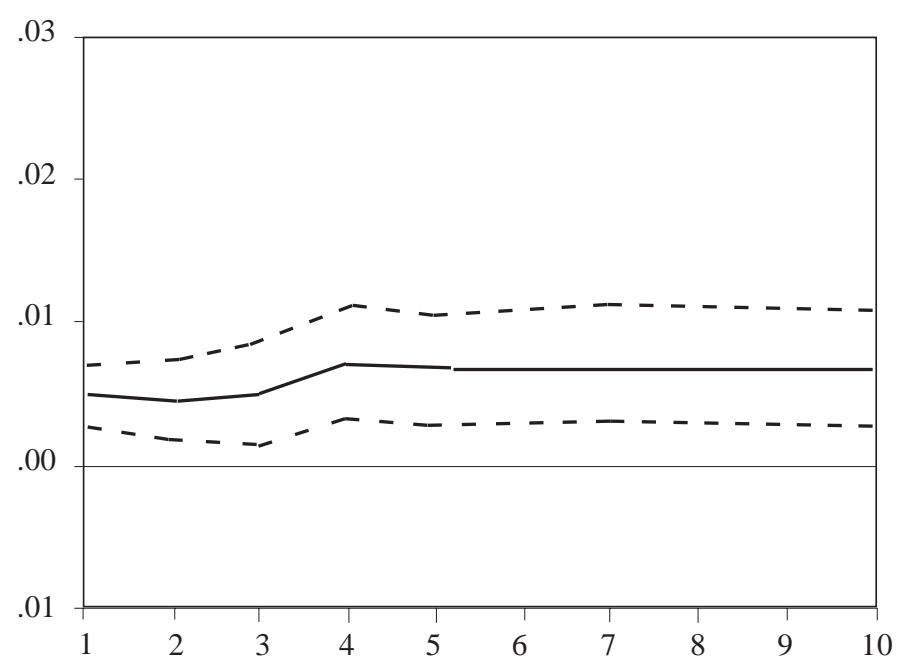


Karim et al.-Integration of Stock Markets between Indonesia and Major Trading Partners

\section{Continued from Figure 2}

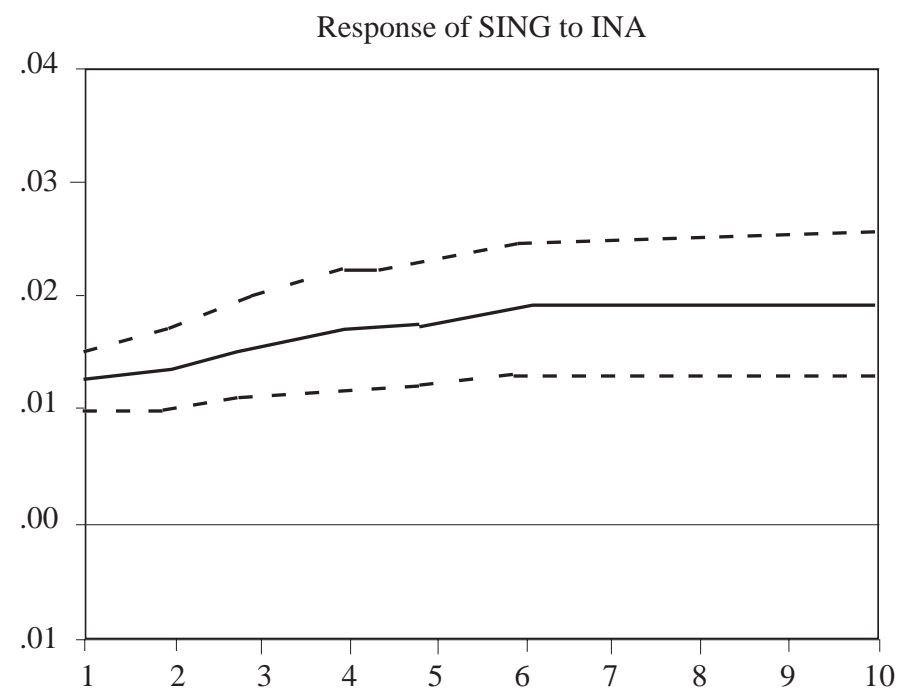

Response of CHN to INA

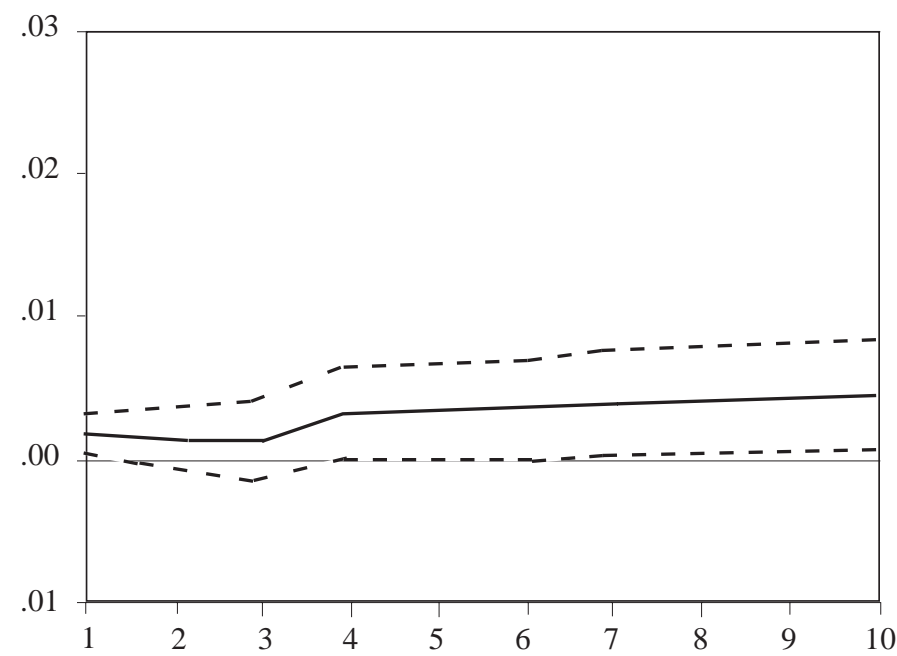


Gadjah Mada International Journal of Business, May-August 2009, Vol. 11, No. 2

In order to provide the dynamic response of the Indonesian stock market to innovations in its major trading partners included in the system, we adopt generalized impulse response functions developed by Pesaran and Shin (1998). The approach is shown to be invariant to the ordering of variables and useful for studies on equity markets, which are generally characterized by quick price transmission and adjustments (Ewing et al. 2003). In addition, it also allows us to examine whether more complex transmission mechanisms are involved (Hutson et al. 2008).

Figure 1 provides the responses of the Indonesian stock market to shocks in its major trading partners while Figure 2 shows the responses of the major trading partners to Indonesian stock market shocks. The shocks in the U.S., Singapore, and Japan are rapidly transmitted to the Indonesian stock market. However, the shocks in China do not significantly influence the Indonesian market. Consistent with our earlier VDCs results, a shock to the Singaporean market has a larger impact on the Indonesian stock market.

At the regional level, the shortrun interdependency between Indonesia and Singapore is clearly identified. This finding is in line with those of Masih and Masih (1997) and Majid et al. (2008). We should note that Indonesia and Singapore are the members of ASEAN, which aims to remove trade barriers amongst its member countries. Taylor and Tonks (1989) note that a stronger financial integra- tion would be expected amongst countries that reduce trade barriers and develop stronger economic ties. The stronger the bilateral trade ties between two countries, the higher of comovements (Masih and Masih 1999; Bracker et al. 1999; Pretorius 2002). In addition, the Indonesian market responds more quickly to shocks in the U.S. than in the Japanese market. The results are consistent with Yang et al. (2003) and Ibrahim (2005) who find evidence that the Asian markets respond quickly to shocks in the U.S. but seem to be less influenced by the Japanese market. Previous work by Chowdhury (1994), Hassan and Naka (1996), and Masih and Masih (1997) also document the relative leading role of the U.S. over Japan in the Asian region. In the context of Asian markets, past studies have documented that the Indonesian market seems to be generally segmented from the advanced markets and other Asian markets. Thus, unlike prior studies (e.g., Palac-Mcmiken 1997; Janakiramanan and Lamba 1998; Dekker et al. 2001), this paper finds that Indonesia is integrated with the advanced and other Asian markets. We could conclude that the Asian stock markets have become more cointegrated after the 1997 financial crisis, a finding similar to those of Sheng and Tu (2000), Yang et al. (2003), Hwahsin and Glascock (2006). In the aftermath of the crisis, Sheng and $\mathrm{Tu}$ (2000) find that the cointegrating relationship has improved in the Asian countries as a whole. This could be partly due to a 
remarkable rising proportion of bilateral trade amongst the countries in the region from pre- to post-crisis period.

Finally, we also note that the Chinese stock market is the most independent and isolated from other markets. The result is consistent with Huang et al. (2000), Lin and Swanson (2008), and with the evidence of our earlier finding of low correlation between China and other markets. Although there have been major reform policies initiated by China such as the implementation of People's Republic of China (PRC) Securities Law (July 1, 1999), the removal of trading restrictions by allowing domestic residents to trade B-share stocks (February 20, 2001), and the opening to Qualified Foreign Institutional Investors (December 1, 2002), but they are still ineffective such that its segmented market continues to provide foreign investors with the benefits of international diversification (Lin and Swanson 2008).

\section{Conclusion and Policy Implications}

This paper examines the stock market integration amongst Indonesia and its major trading partners (i.e., Japan, the U.S., Singapore, and China). This study employs the ARDL approach to cointegration and VAR framework and recent weekly data from July 1998 to December 2007. From the empirical findings, we find evidence that there exists a long-run equilibrium relationship amongst the stock markets. Unlike prior studies, we find that Indonesia is integrated with the advanced and other Asian markets. Since the examined stock markets are cointegrated, there exists a long-run equilibrium relationship amongst them. In addition, the results suggest that the Singaporean and the Indonesian stock markets are complementary in nature rather than competing. From the VAR results, the variations on the Indonesian market respond more to shocks in both the U.S. and Singaporean markets than in the Japanese and Chinese markets. The performance of our estimated error correction representation for ARDL seems to be acceptable. The diagnostic tests perform well, supporting the overall validity of the short-run model.

The existence of cointegration amongst the stock markets also implies a common stochastic trend in those markets (Kasa 1992; Blackman et al. 1994). Since each stock price series contains information on the common stochastic trends (which bind all the markets together), the predictability of a country's stock prices can be enhanced significantly by utilizing information on the other countries' stock prices. The presence of common stochastic trends amongst all these stock markets implies that once new information on a stock price is available prior to other stock prices, the other stock prices will deviate from that trend through a transitory component. Individual prices cannot wander too far away from each other over time (Masih and Masih 1999). 
Gadjah Mada International Journal of Business, May-August 2009, Vol. 11, No. 2

For the purpose of policy making, any development in its major trading partners, particularly the U.S. and Singapore, should be taken into consideration by the Indonesian authorities to design policies pertaining to its stock market. Therefore, the findings of cointegration amongst Indonesia and its major trading partners (i.e., Japan, the U.S., Singapore, and China) imply a need for policy coordination to mitigate the impacts of financial fluctuations. In addition, in order to take advantage of financial integration and interdependence, greater liberalization including reduction or removal of trade and investment barriers will be necessary. To move towards a greater financial integration amongst the markets, trade liberalisation and agreements have important and far-reaching implications in the region. Economic cooperation in the neighbourhood not only strengthens the economic and financial integration, but also enhances greater political stability and social cooperation amongst member nations (Chowdhury 2005).

Similarly, the extent of integration amongst the markets will have an important bearing on the formulation of financial policies of multinational corporations. Therefore, knowing the co-movement amongst the stock markets would give an idea of exchange rate risk between countries. Such knowledge can, therefore, help managers mitigate international risks and manage economic, transaction, and translation risks.

To further add to the existing literature on market integration in the Asian region, further empirical studies on the issue can cover broader areas of market integration and explore other potential factors accounting for market integration. A further possible extension of the study is to quantify and compare the diversification benefits investors can gain when diversifying their investments across the Asian markets. Since cointegrated tests are only able to detect linear longrun equilibrium relationships but fail to detect non-linear cointegration (Okunev and Wilson 1997), a more advanced test is needed to discover the existence of non-linear cointegration amongst the Asian markets.

\section{References}

Aggarwal, R., and M. Mougoue. 1996. Cointegration amongst Asian currencies: Evidence of the increasing influence of the Japanese Yen. Japan and the World Economy 8 (3): 291-308.

Akaike, H. 1974. A new look at the statistics model identification. IEEE Transactions on Atomic Control AC 19: 716-723.

Arshanapalli, B., J. Doukas, and L. Lang. 1995. Pre and post-October 1987 stock market linkages between US and Asian markets. Pacific-Basin Finance Journal 3: 57-73. 
Karim et al.-Integration of Stock Markets between Indonesia and Major Trading Partners

Asian Development Bank. 2008. www.adb.org.

Atkins, F. J., and P. J. Coe. 2002. An ARDL bounds test of the long-run Fisher effect in the United States and Canada. Journal of Macroeconomics 24: 255-266.

Azman-Saini, W.N.W., M. Azali, M. S. Habibullah, and K. G. Matthews. 2002. Financial integration and the ASEAN-5 equity markets. Applied Economics 34: 2283-2288.

Blackman, S. C., K. Holden, and W. A. Thomas. 1994. Long-term relationships between international share prices. Applied Financial Economics 4: 297-304.

Bracker, K., D. S. Dockling, P. D. Koch. 1999. Economy determinants of evolution in international stock market integration. Journal of Empirical Finance 6: 1-27.

Chen, N. F., and F. Zhang. 1997. Correlation, trades and stock returns of the Pacific-Basin markets. Pacific-Basin Finance Journal 5: 559-557.

Cheung, Y. L., and S. C. Mak. 1992. A study of the international transmission of stock market fluctuation between the developed markets and the Asian-Pacific markets. Applied Financial Economics 2: 1-5.

Chowdhury, A. R. 1994. Stock market interdependencies: Evidence from the Asian NIEs. Journal of Macroeconomics 16: 629-651.

Chowdhury, M. B. 2005. Trade reforms and economic integration in South Asia; SAARC to SAPTA. Applied Econometrics and International Development 5 (4): 23-40.

Click, R. W., and M. G. Plummer. 2005. Stock market integration in ASEAN after the Asian financial crisis. Journal of Asian Economics 16: 5-28.

Daly, K. J. 2003. Southeast Asian stock market linkages: Evidence from pre- and postOctober 1987. ASEAN Economic Bulletin 20: 73-85.

Dekker, A., K. Sen, and M. Young. 2001. Equity market in the Asia Pacific region: A comparison of the orthogonalized and generalized VAR approaches. Global Finance Journal 12: 1-33.

Ding, D. K., H. B. H. Frederick, T. L. Sie, and H. M. Thomas. 1999. An investigation of price discovery in informationally-linked markets: Equity trading in Malaysia and Singapore. Journal of Multinational Financial Management 9 (3-4): 317-329.

Engle, R. F., and C. W. J. Granger. 1987. Cointegration and error correction: Representation, estimation, and testing. Econometrica 55: 251-276.

Ewing, B. T., S. M. Forbes, and J. E. Payne. 2003. The effects of macroeconomic shocks on sector-specific returns. Applied Economics 35: 201-207.

Fosu, E. and F. J. Magnus. 2006. Bounds testing approach to cointegration: An examination of foreign direct investment trade and growth relationships. American Journal of Applied Sciences 3: 2079-2085.

Francis, I., S. Kim, and J. H. Yoon. 2002. International stock market linkages: Evidence from the Asian financial crisis. Journal of Emerging Market Finance 1: 1-29.

Goldstein, M., and M. Michael. 1993. The integration of world capital markets. IMF Working Paper (International Monetary Fund). Washington, DC.

Gregory, A. W., and B. E. Hansen. 1996. Residual-based tests for cointegration in model with regime shifts. Journal of Econometrics 70 (1): 99-126. 
Gadjah Mada International Journal of Business, May-August 2009, Vol. 11, No. 2

Grubel, H. 1968. International diversified portfolio: Welfare gains and capital flows. American Economic Review 58: 1299-1314.

Hassan, M. K., and A. Naka, A. 1996. Short-run and long-run dynamic linkages amongst international stock markets. International Review of Economics and Finance 4: 387405.

Huang, B., Y. Chin-Wei, and W. H. John. 2000. Causality and cointegration of stock markets amongst the United States, Japan, and the South China Growth Triangle. International Review of Financial Analysis 9 (3): 93-115.

Hung, B. W., and Y. Cheung. 1995. Interdependence of Asian emerging equity markets. Journal of Business Finance and Accounting 22 (2): 281-288.

Hutson, E., C. Kearney, and M. Lynch. 2008. Volume and skewness in international equity markets. Journal of Banking and Finance 32 (7): 1255-1268.

Hwahsin, C., and J. L. Glascock. 2006. Stock market linkages before and after the Asian financial crisis: Evidence from three greater China economic area stock markets and the U.S.. Review of Pacific Basin Financial Markets and Policies 9 (2): 297-315.

Ibrahim, M. H. 2003. Macroeconomic forces and capital market integration: A VAR analysis for Malaysia. Journal of the Asia Pacific Economy 8 (1): 19-40.

Ibrahim, M. H. 2005. International linkages of stock prices: The case of Indonesia. Management Research News 28 (4): 93-115.

Janakiramanan, S., and A. S. Lamba. 1998. An empirical examination of linkages between Pacific-Basin Stock Markets. Journal of International Financial Markets, Institutions and Money 8: 155-173.

Johansen, S. 1988. Statistical analysis of cointegration vectors. Journal of Economics Dynamic and Control 12: 231-254.

Johansen, S., and K. Juselius. 1990. Maximum likelihood estimation and inference on cointegration with applications to the demand for money. Oxford Bulletin of Economics and Statistics 52: 169-210.

Kasa, K. 1992. Common stochastic trends in international stock markets. Journal of Monetary Economics 29: 95-124.

Kearney, C., and B. M. Lucey. 2004. International equity market integration: Theory, evidence and implications. International Review of Financial Analysis 13: 571- 583.

Kwan, C. H. 2001. Yen Bloc: Towards Economic Integration in Asia. Washington D.C.: Brooking Institution Press.

Laurenceson, J., and J. C. H. Chai. 2003. Financial Reform and Economic Development in China. Cheltenham, UK: Edward Elgar.

Levy, H., and M. Sarnat. 1970. International diversification of investment portfolios. American Economic Review 60: 668-675.

Lin, A. Y., and P. E. Swanson. 2008. The effect of China's reform policies on stock market information transmission. Quarterly Journal of Finance and Accounting 47 (3): 4976. 
Karim et al.-Integration of Stock Markets between Indonesia and Major Trading Partners

MacDonald, R., and C. Kearney. 1987. On the specification of granger-causality tests using cointegration methodology. Economics Letters 25 (2): 149-153.

Majid, M. S. A, A. K. M. Meera, and M. A. Omar. 2008. Interdependence of ASEAN-5 stock markets from the U.S. and Japan. Global Economic Review 37 (2): 201-225.

Masih, A. M. M., and R. Masih. 1997. Dynamic linkages and the propagation mechanism driving major international stock markets. Quarterly Review of Economics and Finance 37: 859-85.

Masih, A. M. M., and R. Masih. 1999. Are Asian stock market fluctuations due mainly to intra-regional contagion effects? Evidence based on Asian emerging stock markets. Pacific- Basin Finance Journal 7: 251-82.

McCauley, R. N., S-S. Fung, and B. Gadanecz. 2002. Integrating the finances of East Asia. BIS Quarterly Review: 83-96.

McKinnon, R., and G. Schnabl. 2003. Synchronised business cycles in East Asia and fluctuations in the yen/dollar exchange rate. World Economy 26: 1067-1088.

Mosconi, R., and C. Giannini. 1992. Non-causality in cointegrated systems: Representation estimation and testing. Oxford Bulletin of Economics and Statistics 54 (3): 399417.

Narayan, P., R. Smyth, M. Nandha. 2004. Interdependence and dynamic linkages between the emerging stock markets of South Asia. Journal of Accounting and Finance 44: 419-439.

Ng, T. H. 2002. Stock market linkages in South-East Asia. Asian Economic Journal 16: 353-377.

Okunev, J., and P. J. Wilson. 1997. Using nonlinear test to examine integration between real estate and stock markets. Real Estate Economics 25: 487-503.

Palac-MicMiken, E. D. 1997. An examination of ASEAN stock markets: A cointegration approach. ASEAN Economic Bulletin 13: 299-311.

Pesaran, M. H., Y. Shin. 1995. An autoregressive distributed lag modeling approach to cointegration analysis. DAE Working Paper No. 9514. Department of Applied Economics, University of Cambridge.

Pesaran, M. H., and Y. Shin. 1998. Generalized impulse response analysis in linear multivariate models. Economics Letters 58: 17-29.

Pesaran, M. H., Y. Shin, and R. Smith. 2001. Bounds testing approaches to the analysis of level relationships. Journal of Applied Econometric 16: 289-326.

Plummer, M. G., and R. Click. 2005. Bond market development and integration in ASEAN. International Journal of Finance and Economics 10 (2): 133-142.

Pretorius, E. 2002. Economic determinants of emerging stock market interdependence. Emerging Markets Review 3: 84-105.

Roca, E. D., E. A. Selvanathan, and W. F. Shepherd. 1998. Are the ASEAN equity markets interdependent. ASEAN Economic Bulletin 15: 109- 120.

Roll, R. 1995. An empirical survey of Indonesian equities 1985-1992. Pacific-Basin Finance Journal 3: 159-192. 
Gadjah Mada International Journal of Business, May-August 2009, Vol. 11, No. 2

Sheng, H., and A. H. Tu. 2000. A study of cointegration and variance decomposition amongst national equity indices before and during the period of the Asian financial crisis. Journal of Multinational Financial Management 10: 345-365.

Sims, C. 1980. Comparison of interwar and postwar business cycles: Monetarism reconsidered. American Economic Review: Papers and Proceedings 70: 250-257.

Solnik, B. H. 1974. Why not diversify internationally. Financial Analysts Journal 30: 4854.

Taylor, M. P., and I. Tonks. 1989. The internationalization of stock markets and the abolition of U.K. exchange control. Review of Economics and Statistics 71: 332-336.

Yang, J., J. W. Kolari, and I. Min. 2003. Stock market integration and financial crisis: The case of Asia. Applied Financial Economics 13: 477-486.

Yu, I-W., L. Fung, and C-S. Tam. 2007. Assessing bond market integration in Asia. Working Paper 10/2007 (June 21). Hong Kong Monetary Authority. HK. 